\title{
Emerging Principles of a Theology of Shalom
}

\author{
PHILIP A. CUNNINGHAM \\ Saint Joseph's University
}

\begin{abstract}
Now that more than five decades have passed since Nostra Aetate initiated a new relationship between Jews and Catholics, it has become possible to identify certain basic principles-predicated on an appreciation of ongoing Jewish covenantal life-that are emerging in Catholic ecclesial statements. Such a "theology of shalom" seeks "right relationship" with the Jewish people and "wholeness" in terms of the church's own self-understanding. The article proposes three fundamental axioms. A theology of shalom (1) sees Jews and Christians as co-covenanting companions; (2) respects and reckons with Jewish selfunderstanding; and (3) focuses on final fulfillment in the future. It elaborates three subpoints for each principle to elucidate several implications and questions. The article concludes with the suggestion that the maturing Catholic-Jewish relationship may be moving into one of mutuality in which both communities can study and learn from their respective covenantal ways of walking with God.
\end{abstract}

Keywords: Catholic-Jewish relations, Christian-Jewish relations, theology of shalom, Nostra Aetate, covenant

\footnotetext{
$\mathrm{S}$ INCE the year 2015 marked the fiftieth anniversary of the Second Vatican Council document Nostra Aetate: Declaration on the Relation of the Church to Non-Christian Religions,$^{1}$ now is an excellent time to take stock of the immense theological transformations that have occurred in
}

${ }^{1}$ Pope Paul VI, Declaration on the Relation of the Church to Non-Christian Religions (Nostra Aetate), October 28, 1965, http://www.vatican.va/archive/hist_councils/ii_vatican_council/documents/vat-ii_decl_19651028_nostra-aetate_en.html.

Philip A. Cunningham, PhD, is Professor of Theology and Director of the Institute for JewishCatholic Relations at Saint Joseph's University in Philadelphia. He has served as president of the International Council of Christians and Jews and on the US Bishops' Advisory Committee on Catholic-Jewish Relations. 
recent decades in terms of Catholic understandings of Jews and Judaism and to consider some current challenges and future possibilities. ${ }^{2}$

Nostra Aetate rejected centuries of hostile Christian presuppositions and teachings about Jews, most particularly that they lay under a curse of divine disfavor, homelessness, and misfortune because of the crucifixion of Jesus. Just as importantly, it launched a positive theological process of unprecedented renewal and creativity. However, in the words of Cardinal Walter Kasper, we are still only at "the beginning of a new beginning" 3 of a deep-seated process of reform.

In published writings, I have referred to this emerging post-Shoah theological tradition as a "theology of shalom." Shalom does not mean simply "peace." It is also "a process of living in wholesome relationship with others, ideally where partners and participants trust each other, act with integrity and are dedicated to the common good rather than threatening each other." 4 Shalom thus seems an extremely appropriate term to apply to recent Christian efforts to develop theologies of "right relationship" with the Jewish people and "wholeness" in terms of the church's own self-understanding. ${ }^{5}$

Even if Christians are only at the beginning of this renewal, it appears that after several decades certain fundamental concepts have been articulated in Catholic ecclesial documents. Without going into all the arguments and perspectives that occurred in the process of refining these concepts, this article sketches the essential features of this emerging Catholic theology of shalom (see appendix 1), and also surveys some practical implications and challenges. It should be stressed that the following statements summarize Catholic theological reflection and do not at all discuss Jewish perspectives on Judaism's relation to Christianity or Jewish responses to these Christian ideas. Such interreligious conversations are among the agenda items for the future.

Though this article is primarily shaped by Catholic perspectives, it is also certainly relevant mutatis mutandis to other Christian traditions. At the

2 This article is based on a lecture for the Faculty of Practical Theology at the University of Vienna presented on November 14, 2016. It draws heavily on my recent book, Seeking Shalom: The Journey to Right Relationship between Catholics and Jews (Grand Rapids, MI, and Cambridge: Eerdmans, 2015), to configure key fundamental principles into a concise and coherent schema not found in the book.

${ }^{3}$ Walter Cardinal Kasper, "Foreword," in Christ Jesus and the Jewish People Today: New Explorations of Theological Interrelationships, ed. Philip A. Cunningham, Joseph Sievers, Mary C. Boys, Hans Hermann Henrix, and Jesper Svartvik (Grand Rapids, MI, and Cambridge: Eerdmans, 2011), xiv, http://ccjr.us/dialogika-resources/documentsand-statements/roman-catholic/kasper/946-kasper201 1mar20.

${ }^{4}$ William Klassen, "Peace," in A Dictionary of Jewish-Christian Relations, ed. Edward Kessler and Neil Wenborn (Cambridge: Cambridge University Press, 2005), 338.

${ }^{5}$ Cunningham, Seeking Shalom, xi-xii, 154-80. 
outset, I want to acknowledge how indebted my theologizing is to the many Jewish colleagues with whom I have had the privilege of team teaching or cowriting. ${ }^{6}$

\section{A. A Theology of Shalom Sees Jews and Christians as Co- Covenanting Companions}

The phrase "co-covenanting companions" attempts to convey in a few words the basic post-Nostra Aetate Catholic understanding of the relationship between Christians and Jews. It encompasses several theological convictions and historical claims, including the following.

1. Christianity and Judaism are intertwined theologically and historically. The interconnections between Jews and Christians begin, of course, with the Jewishness of Jesus, Paul, and the early church; continue through many centuries in a complex process that eventually differentiated post-Temple rabbinic Judaism and the Gentile church; ${ }^{7}$ and unfold in constant interaction in the medieval and modern periods. As John Paul II said during his historic visit to the Great Synagogue of Rome in 1985: "The Jewish religion is not 'extrinsic' to us, but in a certain way is 'intrinsic' to our own religion. With Judaism, therefore, we have a relationship which we do not have with any other religion. You are our dearly beloved brothers and, in a certain way, it could be said that you are our elder brothers." ${ }^{8}$ Such familial metaphors have been reiterated by Popes Benedict XVI and Francis. ${ }^{9}$

${ }^{6}$ I especially thank my colleague and friend Adam Gregerman for his perceptive comments on this article.

7 The phrase "parting(s) of the ways" is a shorthand term for this complex process and was first used in a book title: James D. G. Dunn, ed., Jews and Christians: The Parting of the Ways, A.D. 70-135 (Tübingen: J. C. B. Mohr [Paul Siebeck], 1992). A major topic in the study of the history of Christian-Jewish relations, the debate centers on how early and by what criteria a genuine separation can be clearly delineated. The tendency in the research has been to see ongoing interactions continuing for many centuries after the dates of the two Jewish revolts given in Dunn's subtitle. Two of the most significant works are Daniel Boyarin, Border Lines: The Partition of Judaeo-Christianity (Philadelphia: University of Pennsylvania Press, 2004); and Adam H. Becker and Annette Yoshiko Reed, eds., The Ways That Never Parted: Jews and Christians in Late Antiquity and the Early Middle Ages (Minneapolis: Fortress Press, 2007).

${ }^{8}$ Pope John Paul II, “Address at the Great Synagogue of Rome," April 13, 1986, §4, http:// ccjr.us/dialogika-resources/documents-and-statements/roman-catholic/pope-john-paulii/305-jp2-86apr13.

9 For example, Pope Benedict XVI, "Address at the Great Synagogue of Rome," January 17, 2010, http://w2.vatican.va/content/benedict-xvi/en/speeches/2010/january/documents/ 
While the Jewishness of Jesus is one defining element in the close connections between Christianity and Judaism, it is an open question whether most Christians today have actually considered what this might mean when in their religious imaginations they envision Jesus in the first century. Do they really picture Jesus as "fully a man of his time, and of his environment-the Jewish Palestinian one of the first century, the anxieties and hopes of which he shared,"10 or instead imagine a figure according to various later Christian pieties? In addition, how do Christians conceive of Jesus' interactions with Jewish contemporaries? Is he the foe of an alleged Jewish heartlessness and legalism or a conscientious, Torah-observant Jew engaged in the contemporary debate over how to best observe the Commandments? ${ }^{11}$ Likewise, how many Christians think of the church as being for many decades a movement within the diverse Jewish world of the late Second Temple period? Or, are most Christians comfortable thinking of the church as cleanly and distinctively separated, or even opposed to "Judaism" to some degree from as early as Pentecost, if not from Jesus' ministry itself?

Such considerations lead to the question of how accurately Christian religious education curricula present Jesus and the earliest churches as movements within late Second Temple Judaism. In the United States, all Catholic religion textbook publishers seek certification from the national bishops' conference that their material is in conformity with the 1994 Catechism of the Catholic Church. A statistical analysis of ecclesial documents on relations with Jews showed that pre-1994 textbook series actually scored better than the Catechism in terms of their presentation of Jews and Judaism. ${ }^{12}$ In addition, certifying future religion

hf_ben-xvi_spe_20100117_sinagoga.html; and Pope Francis, Apostolic Exhortation, Evangelii Gaudium, January 24, 2014, $\$ \$ 247-49$, http://w2.vatican.va/content/francesco/en/apost_exhortations/documents/papa-francesco_esortazione-ap_20131124_ evangelii-gaudium.html.

${ }^{10}$ Pontifical Commission for Religious Relations with the Jews, "Notes on the Correct Way to Present Jews and Judaism in Preaching and Catechesis in the Roman Catholic Church," June 24, 1985, III, §12, http://www.vatican.va/roman_curia/pontifical_councils/chrstuni/relations-jews-docs/rc_pc_chrstuni_doc_19820306_jews-judaism_en.html.

${ }^{11}$ For important explorations of this topic, see Hans Hermann Henrix, "The Son of God Became a Human Being as a Jew: on taking the Jewishness of Jesus Seriously for Christology," and Barbara U. Meyer, "The Dogmatic Significance of Christ Being Jewish," in Cunningham et al., Christ Jesus and the Jewish People Today, 114-43 and 144-56, respectively. In the same volume, see the response by Edward Kessler, "Jewish comments on Henrix and Meyer," 157-63.

12 Philip A. Cunningham, Education for Shalom: Religion Textbooks and the Enhancement of the Catholic and Jewish Relationship (Collegeville, MN: Liturgical Press, 1995), 136-52. 
textbooks only in terms of the 1994 Catechism fails to incorporate important later developments in papal teaching and in statements of the Commission for Religious Relations with the Jews and the Pontifical Biblical Commission. ${ }^{13}$ A better and more timely curricular qualitycontrol process is needed for educational materials regarding Jews and Judaism and Christian-Jewish relations.

2. Jews and Christians both covenant with God. In Catholic circles, Nostra Aetate's implicit recognition that the people of Israel abide in a perpetual covenantal relationship with God later became fully explicit. John Paul II, for example, repeatedly taught that Jews are "the people of God of the Old Covenant, never revoked by God," "the present-day people of the covenant concluded with Moses," ${ }^{14}$ and "partners in a covenant of eternal love which was never revoked." 15

The Catholic recognition that Jewish covenantal life was never revoked by God has led to what seem at times to be fruitless discussions about whether there is one covenant with God in which Jews and Christians participate, two distinct covenants for Jews and Christians, or multiple covenants that are serially rearticulated. However, as Rabbi Norman Solomon pointedly observed, "'Covenant' is a metaphor for a relationship, not the name of a unique metaphysical object." ${ }^{16}$ Christian theology

${ }^{13}$ In addition to numerous addresses by Popes John Paul II, Benedict XVI, and Francis, the relevant post-1994 Vatican documents include Pontifical Commission for Religious Relations with the Jews, "We Remember: A Reflection on the Shoah" (1998), http:// www.vatican.va/roman_curia/pontifical_councils/chrstuni/documents/rc_pc_chrstuni_ doc_16031998_shoah_en.html; Pontifical Commission for Religious Relations with the Jews, "The Gifts and the Calling of God Are Irrevocable' (Rom 11:29): A Reflection on Theological Questions Pertaining to Catholic-Jewish Relations on the Occasion of the 5oth Anniversary of Nostra Aetate, no. 4" (2015), http://www.vatican.va/roman_curia/pontifical_councils/chrstuni/relations-jews-docs/rc_pc_chrstuni_doc_20151210_ebraismonostra-aetate_en.html; and Pontifical Biblical Commission, The Jewish People and Their Sacred Scriptures in the Christian Bible (2001), http://www.vatican.va/roman_curia/congregations/cfaith/pcb_documents/rc_con_cfaith_doc_20020212_popolo-ebraico_en.html.

${ }^{14}$ Pope John Paul II, "Address to the Jewish Community in Mainz, West Germany," November 17, 1980, http://ccjr.us/dialogika-resources/documents-and-statements/ roman-catholic/pope-john-paul-ii/297-jp2-8onov17.

15 Pope John Paul II, “Address to Jewish Leaders in Miami," September 11, 1987, http://w2. vatican.va/content/john-paul-ii/en/speeches/1987/september/documents/hf_jp-ii_spe_ 19870911_jewish-org.html.

${ }^{16}$ Norman Solomon, "Covenant" (paper presented at Sacred Heart University, Fairfield, Connecticut, December 4, 2001), §3, http://www.bc.edu/content/dam/files/research_sites/cjl/texts/center/conferences/solomon.htm. For a summary of the concept's historical development, see Simon Schoon, "Covenant," in Kessler and Wenborn, Dictionary of Jewish-Christian Relations, 109-11. 
ought to understand, therefore, that since both Jews and Christians live in relationship with the same God they share certain patterns of experience that resonate in both Israel's and the church's histories. These resonances include God's faithfulness, human weakness, and divine restoration after times of calamity. Covenant should be conceived as a continuing action of covenanting.

3. The Jewish and Christian peoples are covenanting with the Holy One in distinctive yet resonating ways. Without going so far as to apply the transitive law in mathematics woodenly and say that if Jews are covenanting with God and if Christians are covenanting with God then Christians and Jews are covenanting with each other, it still seems inescapable that their ways of covenanting must have some interrelationship because of the One divine covenantal partner. Speaking of Jews and Christians as "cocovenanting" with God conveys both commonality and distinction. The word "companion," literally "one who breaks bread with another," is also significant here. It suggests that Christians and Jews can assist each other in living out their respective covenantal obligations before God, as several decades of deepening dialogue demonstrate. In the process of opening themselves to each other's religious lives through interreligious conversation, Jews and Christians have sometimes discerned a deeper spiritual reality. In their interactions, Jewish and Christian participants have occasionally found themselves glimpsing the elusive presence of the Holy One in the lives and traditions of their dialogue partners. Personally, I have sometimes felt a brush with the Transcendent, when, for example, I discern the profundity of rabbinic debate on some subject or when seeing a friend don tefillin (phylacteries) for prayer. Krister Stendahl's evocative phrase "holy envy" comes to mind. ${ }^{17}$ I realize that these Jewish modes of engagement with the divine presence are not mine. They belong to Jews and their covenantal experience. But I have learned from them and can recognize holiness when I encounter it. To me, this experience of the Holy One across religious lines is a powerful instance of Jews and Christians being "a blessing to one another," in John Paul II's famous phrase. ${ }^{18}$

${ }^{17}$ See Yehezkel Landau, “An Interview with Krister Stendahl," Harvard Divinity Bulletin 35, no. 1 (2007): 29-31.

${ }^{18}$ Pope John Paul II, Message on the Fiftieth Anniversary of the Warsaw Ghetto Uprising, April 6, 1993, http://w2.vatican.va/content/john-paul-ii/en/messages/pont_messages/ 1993/documents/hf_jp-ii_mes_19930406_ebrei-polacchi.html. 


\section{B. A Theology of Shalom Respects and Reckons with Jewish Self- Understanding}

If Jews down through the centuries and still today covenant with God, then their experiences of relationship with God command respect from Christians. This maxim shapes several related concepts and practices.

1. All branches of theology require accuracy regarding Judaism past and present. This is true if only for the self-serving reason that a distorted picture of Jewish traditions will surely produce distorted ideas about Christianity. The 1974 Vatican document "Guidelines and Suggestions for Implementing the Conciliar Declaration Nostra Aetate, 4," declared the following crucial axiom:

[The] links and relationships [binding the Church to Judaism] render obligatory a better mutual understanding and renewed mutual esteem. On the practical level in particular, Christians must therefore strive to acquire a better knowledge of the basic components of the religious tradition of Judaism; they must strive to learn by what essential traits Jews define themselves in the light of their own religious experience. ${ }^{19}$

Among other things, this principle affects Christology, liturgy, ecclesiology, soteriology, ethics, and religious history. It obviously does not mean that Christian theology must always cohere or agree with Jewish perspectives. It does mean that caricatures of Judaism should be excluded from Christian theology. As the US Catholic bishops observed in 1975, "Most essential concepts in the Christian creed grew at first in Judaic soil. Uprooted from that soil, these basic concepts cannot be perfectly understood."20 Indeed, history suggests that the church lacks integrity, becomes less whole-a defining aspect of shalom-when it misrepresents or demeans Judaism. Of course, the most extreme form of repudiating Judaism is the ancient heresy of Marcionism, which among other things rejected the canonical value of Israel's Scriptures. But a related "de-Judaizing process," as the US bishops called it, has distorted Christian self-understanding whenever it "has surfaced from time to

19 Pontifical Commission for Religious Relations with the Jews, "Guidelines and Suggestions for Implementing the Conciliar Declaration Nostra Aetate, 4," December 1, 1974, Preamble, http://www.vatican.va/roman_curia/pontifical_councils/chrstuni/ relations-jews-docs/rc_pc_chrstuni_doc_19741201_nostra-aetate_en.html.

${ }^{20}$ National Conference of Catholic Bishops, "Statement on Catholic-Jewish Relations," November 20, 1975, http://ccjr.us/dialogika-resources/documents-and-statements/ roman-catholic/us-conference-of-catholic-bishops/479-nccb1975. 
time in devious ways throughout Christian history." ${ }^{21}$ Or as Cardinal Kasper vividly expressed it, "Cutting itself off from its Jewish roots for centuries weakened the church, a weakness that became evident in the altogether too feeble resistance against the [Nazi] persecution of Jews."22

To turn to an especially thorny practical matter, if a theology of shalom respects Jewish self-understanding and seeks to defang animosity-producing stereotypes and caricatures of Judaism, the same principle must logically and necessarily apply in the setting of worship and preaching. Perhaps the most vexing challenges arise with regard to the practice of proclaiming the entirety of the Johannine passion narrative on Good Friday. That Gospel's recurrent use of hoi Ioudaioi as the characters who incite Jesus' execution has become highly problematic in post-Shoah Christianity. Thus, for instance, "Guidelines and Suggestions" was concerned to avoid appearing "to arraign the Jewish people as such." ${ }^{23}$ The problem is exacerbated by the real possibility that the evangelist used the term hoi Ioudaioi with the deliberate intention "to implicate both the authorities and the people." ${ }^{24}$ The leading American Catholic Johannine specialist in the late twentieth century, Raymond E. Brown, grappled with the impact of the liturgical proclamation of what he came to call "the anti-Jewish sections" of John and consistently argued as follows:

An initial response ... is to omit the anti-Jewish sections from the public reading of the passion narrative. In my opinion, a truer response is to continue to read the whole passion, not subjecting it to excisions that seem wise to us; but once having read it, then to preach forcefully that such hostility between Christian and Jew cannot be continued today and is against our fundamental understanding of Christianity. Sooner or later Christian believers must wrestle with the limitations imposed on the Scriptures by the circumstances in which they were written. They must be brought to see that some attitudes found in the Scriptures, however explicable in the times in which they originated, may be wrong attitudes if repeated today.... To excise dubious attitudes from the readings of Scripture is to perpetuate the fallacy that what one hears in the Bible is always to be imitated because it is "revealed" by God. ${ }^{25}$

Brown's suggestion that the Johannine passion narrative be read in its entirety with hoi Ioudaioi rendered as "the Jews" means that each year

${ }^{21}$ Ibid.

22 Kasper, "Foreword," xvi.

${ }^{23}$ Commission for Religious Relations with the Jews, "Guidelines and Suggestions," note 1.

${ }^{24}$ Sonya Shetty Cronin, Raymond Brown, "The Jews," and the Gospel of John: From Apologia to Apology (London: Bloomsbury T \& T Clark, 2015), 134.

25 Raymond E. Brown, "The Passion According to John: Chapters 18 and 19," Worship 49 (March 1975): 131; quoted in Cronin, Raymond Brown, 72-73. 
homilists need to exegete the Sitz im Leben of the Gospel to avoid perpetuating late first-century Johannine polemic and hostility. Preachers on Good Friday would then have little time to reflect on the profound religious meaning that the crucifixion of Jesus has for Christians. It would seem that other measures are needed, including some of the strategies that Brown resisted. ${ }^{26}$

There are further unresolved issues concerning the liturgical implications of a theology of shalom. These include how "Old Testament" and Gospel readings are juxtaposed in the lectionary and the inimical lyrics or translations of certain traditional hymns (such as "even as the Old Law ends" or "let all former rites surrender" in the Melvin L. Farrell translation of the traditional Pange Lingua Gloriosi). ${ }^{27}$ Thus, the practical question of how Christian worship can reflect wholeness in relation to Judaism is part of the unfinished agenda for the future.

Another difficult topic involving respect for Jewish self-understanding is the status of so-called messianic Jews. This phrase includes several different groups, most of which self-identify as Jews who have embraced faith in Jesus Christ and wish to assert their continuing identity as Jews. Some claim to be halakically observant as Christ-believers. ${ }^{28}$ Messianic Jews generally see themselves as the spiritual descendants of the first Jewish believers in the Raised Christ.

Although Westerners are inclined to respect personal religious freedom, these various movements raise several disturbing questions for the Christian-Jewish relationship, not least of which is, who defines whether individuals or groups are authentically Jewish? The obvious response is that the Jewish community must have the right to define its own members. Despite the enormously wide variety of Jewish practice and observance that exists today, from secular atheists to the most insular haredim, there is overwhelming unanimity in the judgment that Jews who embrace Christian faith can no longer be considered authentically Jewish. While this unanimity likely taps into painful collective

${ }^{26}$ See Philip A. Cunningham, "Translating and Excerpting the Johannine Passion Narrative for Liturgical Proclamation," SIDIC Review 34, no. 3 and 35, no. 1 (2001-2): 8-18.

${ }^{27}$ See https://www.thetorchbc.com/2014/04/17/praise-we-christ-s-immortal-body-pangelingua-gloriosi/ and http://www.wlp.jspaluch.com/licensedo769.htm.

${ }^{28}$ One of the most theologically sophisticated books from a messianic Jew is Mark S. Kinzer, Postmissionary Messianic Judaism: Redefining Christian Engagement with the Jewish People (Grand Rapids, MI: Brazos Press, 2005). In addition to claiming to be a Torah-observant baptized Jew, he argues for a "bilateral ecclesiology" in which parallel Jewish and Gentile forms of the Christian church exist in a complementary relationship. 
memories of the history of forceful Christian conversions of Jews, surely it is the prerogative of every religious community to determine its membership standards.

Gentile Christians who are positively inclined to recognize the "Jewishness" of "messianic Jews" could be asked by what authority they are competent to adjudicate people's status as Jews. Appeals to the New Testament witness of the originally Jewish churches falter in the face of the fact that so much history has transpired since the first century, and so what is at stake today concerning "messianic Jews" is actually the "relationship of post-biblical rabbinic and Talmudic Judaism-which arose only after the destruction of the Second Temple in the year $70 \mathrm{CE}$-with the church.... Therefore the New Testament can give us no clear answer to the question just posed." ${ }^{29}$ For churches that after the Shoah have committed themselves to learning and respecting Jewish self-understanding, the question of "messianic Jews" will be an ongoing issue.

2. The Jewish and Christian traditions are in dialogue. Virtually every ecclesiastical document issued by a Christian church body since the Second World War encourages interreligious dialogue with Jews. This is a total reversal from previous Christian resistance to "the spiritual dangers to which contact with Jews can expose souls" and of the church's vigilance "to safeguard her children against spiritual contagion," as a $1938 \mathrm{draft}$ text on racism opined. ${ }^{30}$ Learning how to converse openly after centuries of avoidance and disdain, let alone after the Shoah, was not an easy task. Not only did Jews and Christians bring different histories, concerns, and agendas to the table, but they often used the very same words, such as "messiah," with quite different meanings and connotations.

It also quickly became clear that substantive interreligious dialogue was impossible if participants harbored a desire to persuade rather than to learn from each other. This realization has led many Christian communities, including the Catholic Church, to concern themselves no longer with the conversion of Jews, to paraphrase Pope Benedict XVI. ${ }^{11}$

29 Kasper, "Foreword," xiv. Although Kasper was writing specifically about the later "schism between Judaism and Christianity," his observation about the New Testament predating this gradual split is pertinent for "messianic Jews" as well.

${ }^{30}$ Quoted phrases are from the 1938 draft of an encyclical commissioned by Pope Pius XI, but never completed, Humani Generis Unitas, §142. See Georges Passelecq and Bernard Suchecky, The Hidden Encyclical of Pope Pius XI (New York: Harcourt, Brace, 1997), 246-59.

${ }^{31}$ Pope Benedict XVI, Jesus of Nazareth: Holy Week; From the Entry into Jerusalem to the Resurrection (San Francisco: Ignatius Press, 2011), 42. 
Over the decades several Catholic prelates have argued that the ultimate destiny of Jews is in the hands of the God with whom they covenant and is therefore not a project for the church. ${ }^{32}$

The deepening of dialogue has occurred simultaneously with an increasing sophistication in the use of scriptural texts by the Jewish and Christian traditions. Recent Catholic ecclesial statements on biblical hermeneutics explain that normative texts are continuously read afresh through new lenses. In particular, Jews and Christians constantly "reread" their sacred texts in the context of their ever-changing experiences and histories. ${ }^{33}$ Striking examples of this dynamic are evident from the earliest centuries of Christianity and rabbinic Judaism. Those Jews who became convinced that the Crucified One had been transcendently "raised" began to reread the Scriptures of ancient Israel with Christ as their primary "lens." Similarly, after the Roman destruction of the Jerusalem temple in $70 \mathrm{CE}$, certain Jews reread and reinterpreted the Torah and the Commandments in creatively different ways, leading eventually to the rise of rabbinic Judaism.

Commenting on the custom that Jews and Christians share of retrospectively "rereading" the Scriptures, a 2001 Pontifical Biblical Commission study observed:

Christians can and ought to admit that the Jewish reading of the Bible is a possible one, in continuity with the Jewish Sacred Scriptures from the Second Temple period, a reading analogous to the Christian reading which developed in parallel fashion. Each of these two readings is part of the vision of each respective faith of which it is a product and

32 See Philip A. Cunningham, "Official Ecclesial Documents to Implement the Second Vatican Council on Relations with Jews: Study Them, Become Immersed in Them, and Put Them into Practice," Studies in Christian-Jewish Relations, Oct. 2009, http:// escholarship.bc.edu/scjr/vol $4 /$ iss1/24.

${ }^{33}$ For example, Pontifical Biblical Commission, "The Interpretation of the Bible in the Church" (1993), §III, A, 1, http://ccjr.us/dialogika-resources/documents-and-statements/romancatholic/vatican-curia/287-pbc-1993: "One thing that gives the Bible an inner unity, unique of its kind, is the fact that later biblical writings often depend upon earlier ones. These more recent writings allude to older ones, create 'rereadings' (relectures) which develop new aspects of meaning, sometimes quite different from the original sense." See also Pontifical Biblical Commission, The Jewish People and Their Sacred Scriptures, §II, A, 2: "In Judaism, re-readings were commonplace. The Old Testament itself points the way. For example, in the episode of the manna, while not denying the original gift, the meaning is deepened to become a symbol of the Word through which God continually nourishes his people (cf. Dt 8:2-3). The Books of Chronicles are a re-reading of the Book of Genesis and the Books of Samuel and Kings. What is specific to the Christian rereading is that it is done, as we have said, in the light of Christ." 
an expression. Consequently, they cannot be reduced one into the other. On the practical level of exegesis, Christians can, nonetheless, learn much from Jewish exegesis practiced for more than two thousand years, and, in fact, they have learned much in the course of history. For their part, it is to be hoped that Jews themselves can derive profit from Christian exegetical research. ${ }^{34}$

These words offer a dramatic contrast to the perennial debates between Christians and Jews over who interpreted the Scriptures correctly. Not only are Christological readings of the "Old Testament" perceived to be retrospective, but the Jewish traditions of the rabbis, especially as contained in the Talmud, are themselves seen as retrospective interpretations of the Tanakh. Most significantly, since Jewish rereadings are "analogous" to Christian retrospective processes of interpretation, they have legitimacy and value. Pope Benedict made this point powerfully when he wrote in 2011: "After centuries of antagonism, we now see it as our task to bring these two ways of rereading the biblical texts-the Christian way and the Jewish way-into dialogue with one another, if we are to understand God's will and his word aright." 35 Most provocative is Benedict's intimation that if Jews and Christians do not bring their distinctive traditions of interpretation into conversation with one another, they run the risk of not understanding "God's will and his word aright." Pope Francis has echoed the unique possibilities of Jews and Christians being study partners together in exploring their sacred texts: "There exists as well a rich complementarity which allows us to read the texts of the Hebrew Scriptures together and to help one another to mine the riches of God's word" (EG \$249).

This prospect inspired Saint Joseph's University to commission an original sculpture to celebrate the fiftieth anniversary of Nostra Aetate. Entitled "Synagoga and Ecclesia in Our Time," it depicts the church and synagogue not as foes but as friends learning from each other about God (see appendix 2).

From this hopeful vision for the future relationship, about which more will be said below, there remains one particular aspect of Jewish selfunderstanding that is especially difficult for Christians to grasp: the centrality for Jews of the Land of Israel (Eretz Yisrael). This is because the Land of Israel is not inextricably connected to Christian theology, it has no central place in the Christian effort to live as Christ, and Christians around the world have no deeply felt liturgical yearning for the Land or

${ }^{34}$ Pontifical Biblical Commission, The Jewish People and Their Sacred Scriptures, II, A, 7.

35 Pope Benedict XVI, Jesus of Nazareth, 35. 
for Jerusalem, except perhaps in the sense of the heavenly or eschatological Jerusalem. It is true that for many Christians the region has a historical or even a sacramental aspect ${ }^{36}$ as the place where Jesus lived and died, and so there is also a history of pilgrimages there.

Palestinian Christians uniquely see themselves as heirs in the Land itself to the Christian faith passed down from the Apostles and their successors: "The generations of the faithful have kept it throughout the course of many centuries, through the various periods of history and the successive civilizations." 37 If Christians elsewhere do not often need to think religiously about the Land of Israel, that is not the case for Palestinian Christians. ${ }^{38}$ Often applying to themselves Jesus' words in Luke 12:32, "Do not be afraid, little flock," they are a tiny and vulnerable minority among much larger populations of Jews and Muslims, and their seemingly interminable situation of statelessness creates serious hardships for the practice of their faith. ${ }^{39}$ But perhaps this singular context provides some Palestinian Christians with a vision for a particular mission of interreligious reconciliation that could inspire many others: "Moved by a genuine spirituality, all believers of the three monotheistic religions could work together to make this city [Jerusalem] really become what God wants it to be: a place of

${ }^{36}$ See Richard C. Lux, The Jewish People, the Holy Land, and the State of Israel: A Catholic View (New York and Mahwah, NJ: Paulist Press, 2010).

37 First Pastoral Letter of the Latin Patriarch of Jerusalem, Michel Sabbah, In Pulcritudinus Pacis (1988), §7, https://www.lpj.org/first-pastoral-letter-of-patriarch-michel-sabbah/.

${ }^{38}$ However, it is worth mentioning that Christians and Jews around the world who have been engaged in friendly dialogue for many years suddenly find themselves arguing fiercely when the Israeli-Palestinian conflict is discussed. The topic has a profoundly polarizing character, especially when political and religious aspects are conflated. A forthcoming volume entitled Promise, Land, and Hope: Resources for Constructive Dialogue about Israeli-Palestinian Issues, from a research project sponsored by the International Council of Christians and Jews and several American and European universities, seeks to provide resources to overcome this endemic polarization.

39 Two particular pastoral problems confronting Palestinian Catholics and other Christians might be briefly noted here. First, understandably reacting negatively to biblical references to "Israel" because they relate them to their experiences of the modern Israeli state, they can find it difficult to draw spiritual sustenance from the Old Testament. See the pastoral letter of Patriarch Michel Sabbah, "Reading the Bible in the Land of the Bible," November 1, 1993, \$56, http://www.lpj.org/newsite2006/patriarch/pastoralletters/1993/readingthebible_en.html. In addition, the reception of Nostra Aetate among Palestinian Catholics is difficult because of fears that a new Catholic relationship with Jews can contribute to legitimizing their own physical supersession on the land by Israelis. See the commentary of Jamal Khader and David Neuhaus, SJ, "A Holy Land Context for Nostra Aetate," Studies in Christian-Jewish Relations 1 (2005-6): 68-73, http://escholarship.bc.edu/scjr/volı/iss1/art8. 
encounter with God, and consequently a place to inspire peace and reconciliation in hearts and minds." 40

To return to the summary of Christian attitudes about the Land of Israel more generally, Christianity strongly emphasizes that God can be encountered anywhere, that holiness may be found in any land or place. Indeed, far from resonating with the centrality of Eretz Yisrael for Judaism, there is what might be called "a counter-history" of Christian denial of a Jewish covenantal bond with the Land. Supersessionist Christianity claimed that Jews had forfeited any religious tie to the Land because of their alleged collective guilt for the crucifixion of Jesus. Those who polemicized against Judaism argued that God had cursed all Jews, proven by the destruction of the Temple and the supposed condition of Jews as homeless wanderers. ${ }^{41}$

All these factors make it very difficult for most Christians to resonate with the spiritual significance of the Land of Israel for Jews. They have no cognate covenantal connection, they stress the universality of the Christian gospel, and they have long precedents of rejecting any ongoing Jewish spiritual ties to the Land.

The Vatican has attempted to balance these various factors, and its efforts illustrate the conundrum faced by a Christian tradition that rejects biblical fundamentalism, is committed to rapprochement and understanding with Jews, believes that God's presence can be seen in human history, and upholds the human rights of all people. Its basic outlook can be outlined in three points from a 1985 Vatican document, as follows.

${ }^{40}$ Fifth Pastoral Letter of the Latin Patriarch of Jerusalem, Michel Sabbah, "'Seek Peace and Pursue It' (Ps. 34:14)” (1998), \$40, http://www.lpj.org/newsite2006/patriarch/pastoralletters/1998/seek_the_peace1998_en.html. Though Sabbah here wrote specifically about Jerusalem, this vision can be extended to the wider region. Note the similar comments in Pope Francis, "Letter of His Holiness Pope Francis to the Christians in the Middle East," December 21, 2014, https://w2.vatican.va/content/francesco/en/letters/ 2014/documents/papa-francesco_20141221_lettera-cristiani-medio-oriente.html: "You are a small flock, but one with a great responsibility in the land where Christianity was born and first spread. You are like leaven in the dough. Even more than the many contributions which the Church makes in the areas of education, healthcare and social services, which are esteemed by all, the greatest source of enrichment in the region is the presence of Christians themselves, your presence.... Your efforts to cooperate with people of other religions, with Jews and Muslims, is another sign of the Kingdom of God."

${ }^{41}$ See Adam Gregerman, Building on the Ruins of the Temple: Apologetics and Polemics in Early Christianity and Rabbinic Judaism (Tübingen: Mohr Siebeck, 2016). 
a. Christians cannot think of Jews as punished and so divinely detached from Eretz Yisrael.

b. The continued existence of the Jewish people, B'nai Yisrael or 'Am Yisrael, is God's will.

c. Christians should respect and seek to understand Jewish attachment to Eretz Yisrael, without necessarily adopting it themselves, while the existence of the modern State of Israel (Medinat Yisrael) should not be interpreted primarily in religious or biblical categories, but according to current international law. ${ }^{42}$

With respect to the third point (c), the State of Israel is a nation-state that is not coextensive with the covenanting community of B'nai Yisrael (i.e., the Jewish people), even though Eretz Yisrael is a defining reality for the Jewish people as a whole. But there is an unresolved tension here: methodologically, how do Christians go about respecting the religious centrality of the Land of Israel for Jews while considering the modern State of Israel only in terms of distinct, nonreligious international legal norms? Moreover, since both Judaism and Christianity are premised on the idea that God is involved in human history, a radical disjuncture between the "secular" and "religious" realms cannot be rigidly maintained in either tradition without undermining their respective truth claims.

Clearly, developing a Christian theological appreciation of the centrality of Eretz Yisrael for Jews is a priority in the years ahead. I strongly suspect that intense dialogue with sympathetic Jewish colleagues, who face their own variations on these challenges, is essential for any progress to be made.

3. Mutuality in theologizing is preferable to binary or oppositional thinking. Both the Jewish and Christian communities became habituated over the centuries to defining their respective identities in zero-sum opposition to one another. This "oppositional self-definition" is a cause of stereotyping. It promotes the reflexive impulse that if Christians believe such and such then Jews must not, and vice versa. Therefore, until fairly recently it has been difficult for both Christians and Jews to engage the core religious truth claims of the other with anything other than rejection because their respective self-understandings are viscerally implicated. The borders between their communities that for centuries helped define their respective identities could become uncomfortably blurred and altered as they learn

${ }^{42}$ Commission for Religious Relations with the Jews, "Notes on the Correct Way to Present Jews and Judaism," VI, §25. 
they have misconstrued the other's positions. Christians who affirm Jewish perspectives can be accused of "watering down the faith" or even of "apostasy." Jews who affirm Christian perspectives can be accused of abandoning their Jewish heritage and assimilating into the wider culture.

One manifestation of oppositional, binary thinking is the widely shared assumption among both most Christians and Jews that "something went wrong" with the origins of Christianity and rabbinic Judaism as discrete communities. This separation is thought to have been contrary to God's will. Christians can consciously or unconsciously imagine that most Jews did not accept the Good News about Jesus because God "blinded" them (following Paul in Romans 11:25), or because Jews were innocently mistaken because of a misplaced myopic focus on the Torah, or less benignly, because of their obstinacy. ${ }^{43}$ Jews may consciously or unconsciously assume that if not Jesus, then Paul distorted the essence of Judaism and so created the fundamentally misguided Gentile church. ${ }^{44}$

I suggest an alternative presupposition to "something went wrong" in retelling the Christian story today. Why can we not suppose that the origins of our two traditions unfolded according to God's will? Is it not possible that the Holy One, whom Christians experience as intensely relational even within God's own being, would desire two related covenanting communities in the world, perhaps to serve as enablers and correctors of one another?

Moving beyond binary categories is also helpful in considering the major Christological and soteriological question that has arisen with the recent Christian affirmation of the Jewish people's ongoing covenantal life with God: How can Christians reaffirm their faith-conviction that Christ is the savior of all humanity even while affirming that Jews covenant with God despite the fact that they reject that Christian claim? ${ }^{45}$ Instead of conceiving of the question in either/or terms-either people

43 N.B. the words of the Pontifical Biblical Commission in 2001: "Accordingly, excessive insistence, characteristic of a certain apologetic, on the probative value attributable to the fulfillment of prophecy must be discarded. This insistence has contributed to harsh judgments by Christians of Jews and their reading of the Old Testament: the more reference to Christ is found in Old Testament texts, the more the incredulity of the Jews is considered inexcusable and obstinate." The Jewish People and Their Sacred Scriptures, \$21.

44 So, e.g., Hyam Maccoby, The Mythmaker: Paul and the Invention of Christianity (San Francisco: Harper San Francisco, 1986).

45 This question drives the essays collected in Cunningham et al., Christ Jesus and the Jewish People Today. 
"believe in" Christ Jesus or they do not-Christian theologians can, for example, delve more deeply into the church's experience of God's inviting Word incarnated in Christ and resonate with that Word's obvious presence in the ongoing covenanting community of the Jewish people. ${ }^{46}$ This line of thinking was evident in the most recent Vatican document on Christian-Jewish relations:

God revealed himself in his Word, so that it may be understood by humanity in actual historical situations. This Word invites all people to respond. If their responses are in accord with the Word of God they stand in right relationship with him. For Jews this Word can be learned through the Torah and the traditions based on it. The Torah is the instruction for a successful life in right relationship with God. Whoever observes the Torah has life in its fullness (cf. Pirqe Avot II, 7). By observing the Torah the Jew receives a share in communion with God. ${ }^{47}$

This passage has unmistakable soteriological cadences. Jews are able to stand in "right relationship" or share "in communion with God" or have "life in its fullness" (evoking John 10:10) because of the positive assertion that "for Jews the Word of God is present above all in the Torah." Much more could obviously be said about this "LogosChristology" in terms of a theology of revelation, pneumatology, and Christian Trinitarianism. The point here is that theological progress concerning Christian-Jewish relations often depends on overcoming binary habits of thinking that both Christians and Jews have inherited from our long history of opposition. Thinking in terms of mutuality is therefore one of the foundations of a theology of shalom.

\section{A Theology of Shalom Focuses on Final Fulfillment in the Future}

The claim that the church has "fulfilled" God's promises to Israel goes back to the earliest Christian writings. Traditionally, though, it is closely associated with the idea that Judaism has been rendered obsolete through its "fulfillment" by Christianity. It is thus very noteworthy that most post-Nostra

${ }^{46}$ For further details and for the relevance of conceiving of the Word as the triune God's invitation to relationship, see Philip A. Cunningham and Didier Pollefeyt, "The Triune One, the Incarnate Logos, and Israel's Covenantal Life," in Cunningham et al., Christ Jesus and the Jewish People Today, 183-201.

${ }^{47}$ Commission for Religious Relations with the Jews, “'The Gifts and the Calling of God Are Irrevocable,"” \$24. 
Aetate Vatican documents on relations with Jews frame the discussion of "fulfillment" explicitly in the terms of a futurist or unrealized eschatology. ${ }^{48}$ There is an "already," but also a "not yet."

1. Jews and Christians have different but converging expectations. Because of our difficult history together, Christians and Jews often operate with a sort of theological "default program" that steers them to think in oppositional or binary terms. This is also seen in widespread zero-sum speculations about what will happen at the end of days. Jews and Christians tend to imagine that at the dawning of the messianic age one tradition will finally learn that it was wrong and that the other was right. Some Christians envision that Jews will finally recognize their error in failing to acknowledge Jesus Christ as the Messiah and Son of God. On the other hand, some Jews "believe that the worship of Jesus as God is a serious religious error displeasing to God even if the worshipper is a non-Jew, and that at the end of days Christians will come to recognize this." 49

Such binary thinking, which basically casts Jews and Christians in the role of either winners or losers, seems increasingly self-serving as the new relationship between Jews and Christians deepens and both come to greater appreciation of the reflection of the Holy One in each other. As friendship between Christians and Jews grows, this tendentiousness seems more and more incompatible with the gracious, covenanting God of Israel and the church. Surely, Christian theologians who are committed to overcoming supersessionism toward the Jewish people and tradition can be more creative than simply postponing the hour (even into the unknowable future) when Jews will supposedly acknowledge the error of their ways. Such assumptions must surely impede Christians from coming to honor the inherent value of Jewish covenantal life and thus impair their ability to be fully open to learning from Jews' experiences of God. A 2001 Pontifical Biblical Commission study is very thought-provoking in this regard:

What has already been accomplished in Christ must yet be accomplished in us and the world. The definitive fulfillment will be at the end with the resurrection of the dead, a new heaven and a new earth.

${ }^{48}$ E.g., Commission for Religious Relations with the Jews, "Guidelines and Suggestions," II, Liturgy; Commission for Religious Relations with the Jews, "Notes on the Correct Way to Present Jews and Judaism," §9; cf. §11.

49 David Berger, "On Dominus Iesus and the Jews" (paper presented at the 17th Meeting of the International Catholic-Jewish Liaison Committee, New York, May 1, 2001), http:// ccjr.us/dialogika-resources/documents-and-statements/analysis/498-bergeroımayı. 
Jewish messianic expectation is not in vain. It can become for us Christians a powerful stimulus to keep alive the eschatological dimension of our faith. Like them, we too live in expectation. The difference is that for us the One who is to come will have the traits of the Jesus who has already come and is already present and active among us. ${ }^{50}$

The use of such expressions as "we too live in expectation" and "the eschatological dimension of our faith" indicates that both Judaism and the church will, in a sense, be superseded in the reign of God. The practices of both traditions will be altered in the age to come. For example, Catholic sacramental life will be rendered obsolete by life in God's direct presence, ${ }^{51}$ and while rabbinic traditions describe the joys of the age to come in terms of the sublimity of Torah study or the physical pleasures of meals or sex, there are also texts that imagine a new, immediate experience of God, such as "The righteous sit with their crowns on their heads and receive pleasure from the radiance of the Divine Presence."52

In particular, the formulation that the eschatological messiah will have "the traits of Jesus," which would be recognized as such by Christians, is very notable. Crucially, Jewish recognition of the eschatological "One who is to come," since their "messianic expectation is not in vain," must logically depend on Jews perceiving some identifiable messianic "traits" conveyed through the Jewish tradition. One way of conceiving of these messianic matters, although there are diverse ideas both among and between Jews and Christians, is that the eschatological messiah will therefore be recognizable by both Jews and Christians on the basis of different legitimate but converging "traits." It follows that each community, by seeing each other's recognition, would fully understand for the first time the "rightness" of not only its own point of view, but of the other's as well. What had been opaque about the other in historical time would become transparent in eschatological "time."

50 Pontifical Biblical Commission, The Jewish People and Their Sacred Scriptures, §21.

${ }^{51}$ See, e.g., Catechism of the Catholic Church (1994): "All the sacraments ... have as their goal the last Passover of the child of God, which, through death, leads him into the life of the Kingdom. Then what he confessed in faith and hope will be fulfilled, 'I look forward to the resurrection of the dead and the life of the world to come"” (\$1680); "For the Christian the day of death inaugurates, at the end of his sacramental life, the fulfillment of his new birth begun at Baptism, the definitive 'conformity' to 'the image of the Son' conferred by the anointing of the Holy Spirit, and participation in the feast of the Kingdom which was anticipated in the Eucharist" (\$1682). http://ccc.usccb.org/ flipbooks/catechism/index.html\#418/z.

52 Tractate Kallah Rabati 2:3; http://www.inner.org/sefirot/sefketer.htm. 
This all means that the traditional Christian language of "fulfillment" is significantly modified in a theology of shalom. In particular, projected eschatological scenarios need to have much greater sophistication than simplistic zero-sum phrases like "a Jewish turn to Christ" or "Christians will see their error." The God of Israel and of Christ Jesus deserves better theologizing than that. If Christians and Jews are to live in shalom, in right relationship with each other, then theologies that promote mutuality are required.

2. Jews and Christians have proleptically experienced God's ultimate future. Whatever the ineffable eschatological future may bring, both Christians and Jews understand that they have encountered or encounter today foretastes of God's reign. Although it is sometimes said that Christians stress that the redemption of the world has begun (or even already happened) and Jews emphasize the unredeemed state of the world, both in different ways see themselves as experiencing anticipations of the age to come. For example, Jews see the Shabbat as a taste of the messianic era, while Christians understand that by his resurrection, "Jesus is introduced into "the world to come.'"53 The fact that both traditions hold that they have known such "prolepses," such premature eruptions of God's "time" into historical time, is a foundational premise that a theology of shalom could develop further. One could even imagine some sort of prayer experience in which Jews and Christians together look forward to the full realization of God's intentions for creation.

3. God's freedom of action, God's "mystery," is a primary reality. The preference for futurist eschatological perspectives in a theology of shalom is related to a certain epistemological humility that is required when confronting the mystery of Israel and the mystery of the church. Of course, the term "mystery" is employed here in its technical theological sense of something that ultimately cannot be fully grasped by mortal human minds. This is important to remember as Christians theologize about their relationship with Jews. As people immersed in linear space-time, we cannot expect or presume to attain full comprehension of all God's plans for Jews and Christians, or all humanity. We can see the same awareness reflected in the faces of our Jewish companions and together trust in the One who has called us into being as covenanted peoples.

53 Pontifical Biblical Commission, "Instruction on Scripture and Christology," January 6, 1984, \$1.2.6.2, http://ccjr.us/dialogika-resources/documents-and-statements/romancatholic/vatican-curia/288-pbc-1984. 


\section{Conclusion: Moving into Mutuality}

All the above leads me to conclude that Christians and Jews have in our day (nostra aetate) the possibility of developing an unprecedented depth of relationship. We are beginning to chart the unexplored paths of mutuality. "Mutuality" in this context means a deepening love for the distinctiveness of the Jewish or Christian other because of their edifying ways of walking with God. The companionship that this presupposes inevitably produces a reconfiguration of the crude oppositional borders that both traditions received from their hostile past. To that extent, Christians and Jews will not be the same as they were before substantively engaging with each other, but if the testimony of many dialogue veterans over the past decades is any indication, they will understand their respective Christianity and Jewishness more deeply than would otherwise have been possible. In addition, the mutual enrichment generated by the new relationship between Jews and Christians offers profound hope for a wide variety of long-lasting conflicts around the world. In response to a question about what metaphor might best describe the emerging Christian-Jewish relationship today, Daniel Lehmann has proposed the following:

I would like to suggest ... what in Aramaic we [Jews] call a havruta, that is a learning partner. A learning partner is someone with whom you study texts, biblical or other kinds of traditional texts, but you study it in order to have a dialogue-an interlocutor, with whom truth can emerge as you play out your different perspectives on the texts. And it's a kind of relationship which is very intimate, in which there is a sense of shared texts, and even a covenantal relationship, but in which the partners are not just trying to agree, but in fact, trying to see how their different perspectives can enhance the other person's understanding. Again, I would like [Christian-Jewish relations] to shift from dialogue to learning. I think it's really about sharing insights and interpretations in the common texts that we share and some that we don't share. ${ }^{54}$

I believe that fifty years along what Pope Francis has called "our journey of friendship," 55 Christians and Jews are learning that we can explore and study

${ }^{54}$ Daniel Lehmann, quoted at 07:18-8:32, in "Metaphors for a Unique Relationship," Walking God's Path: Jews and Christians in Candid Conversation [video series], produced by Philip A. Cunningham, John Michalczyk, and Gilbert Rosenthal (Boston: Center for Christian-Jewish Learning at Boston College, 2004), episode 5, http://ccjr. us/dialogika-resources/educational-and-liturgical-materials/curricula/958-wgp-1.

55 Pope Francis, "Address to the Two Chief Rabbis of Israel," May 26, 2014, http://w2. vatican.va/content/francesco/en/speeches/2014/may/documents/papa-francesco_20140526_terra-santa-visita-rabbini-israele.html. 
profound questions together as study partners with a closeness and trust that was unimaginable not so long ago.

In the process of studying their traditions together and sharing their respective experiences of covenant with God, Jews and Christians will also be challenged to reconsider the nature of their interrelationship. While Christians must almost necessarily see themselves as closely connected with Jews-or risk falling into the heresy of Marcionism-the reverse is by no means the case for Jews regarding Christianity.

Rabbi Joseph Soloveitchik, who at the time of the Second Vatican Council was a leading American voice among those "modern Orthodox" who were open to interactions with the wider culture, urged in an influential 1964 article entitled "Confrontation" that Jews avoid theological discussions with Christians. ${ }^{56} \mathrm{He}$ offered several arguments for this conclusion, some of which have proven to be flawed over the ensuing five decades. However, one, illustrated with the following excerpts, is probably of abiding significance:

It is self-evident that a confrontation of two faith communities is possible only if it is accompanied by a clear assurance that both parties will enjoy equal rights and full religious freedom.... Any intimation, overt or covert, on the part of the community of the many [Christians] that it is expected of the community of the few [Jews] that it shed its uniqueness and cease existing because it has fulfilled its mission by paving the way for the community of the many, must be rejected as ... contravening the very idea of religious freedom. The small community has as much right to profess its faith in the ultimate certitude concerning the doctrinal worth of its world formula and to behold its own eschatological vision as does the community of the many.

We [Jews] certainly have not been authorized by our history, sanctified by the martyrdom of millions, to even hint to another faith community that we are mentally ready to revise historical attitudes, to trade favors pertaining to fundamental matters of faith, and to reconcile "some" differences.... Only a candid, frank, and unequivocal policy reflecting unconditional commitment to our God, a sense of dignity, pride, and inner joy in being what we are, believing with great passion in the ultimate truthfulness of our views, praying fervently for and expecting confidently the fulfillment of our eschatological vision when our faith will rise from particularity to universality, will impress the peers of the other faith community among whom we have both adversaries and friends. ${ }^{57}$

${ }^{56}$ His continuing influence is apparent in the recent statement by the Conference of European Rabbis and the Rabbinical Council of America, "Between Jerusalem and Rome: The Shared Universal and the Respected Particular-Reflections on 50 Years of Nostra Aetate," March 2016, http://ccjr.us/dialogika-resources/documents-and-statements/jewish/1421-cer-rca-2016; see esp. the section "Evaluation and Reevaluation."

57 Joseph B. Soloveitchik, “Confrontation," Tradition 6, no. 2 (1964): 22-24. 
Among other things, Soloveitchik was rightly concerned with the overwhelmingly superior number of Christians (everywhere except in the State of Israel). How could "both parties enjoy equal rights," be equal partners at the dialogue table, given the huge demographic disadvantage faced by Jews? He felt that Christianity's numerical dominance meant that there could never exist the "level playing field" that would be an absolute precondition for theological dialogue.

Soloveitchik, though, has identified a more subtle, interpersonal risk, especially for Jews. He perceived that normal human social interaction could exert a desire to "trade theological favors" with one another in reciprocal fashion, to respond in kind to what seems to be a generosity of spirit in the dialogue partner. That human impulse could result in a dangerous loss of identity, particularly for the minority group.

One must acknowledge the legacy of oppositional self-definition that is also at work here, and Soloveitchik has perceived a genuine issue. However, the experience of the last fifty years of a historically unprecedented Christian-Jewish dialogue has shown that the encounter almost invariably results in a deepening of one's religious identity - not in its deteriorationprecisely because of the engagement with the religious other. I am not the same Catholic I was before engaging in dialogue with Jews, but I understand and am committed to my enriched Catholicity more profoundly than before. Jewish dialogue partners have periodically expressed the same sentiment.

This means that the future Catholic-Jewish dialogue needs from time to time to reflect upon the dynamics of the emerging new relationship. What happens when reforming one's theology in response to more accurate understandings of the Jewish or Christian other becomes intermingled with the natural desire for them to reciprocate? How do we reconfigure identities that were partially defined in response to rejection and hostility on the other's part when today the other is encountered as a friend? How is covenantal distinctiveness to be redefined when the boundaries between the two traditions shift because of achieving a more profound awareness of each other? What existential forms will "complementarity" and "mutuality" between Christians and Jews take in the coming decades? These are among the questions that they must also tackle in the future if their new relationship is to deepen and grow.

These reflections can be summarized in this way: in the aftermath of the abomination that was the Shoah, Catholic theology had to begin to reform itself radically in order to begin to speak meaningfully with Jews. Traumatized Jews had to struggle with whether to risk speaking with any Christians at all. Was a new relationship even possible, let alone desirable? Decades later, we have encountered holiness in each other and are starting to learn much from each other. We are beginning to feel secure enough 
with each other, as Pope Francis has written, "to lower the defenses, to open the doors of one's home and to offer warmth." ${ }^{88}$ It appears that it is the new relationship itself that is assuming a primary value. It is becoming the very space $^{59}$ within which both Jews and Catholics can theologize, where they can seek to deepen their understanding of relationship with God.

And in deepening their relationship with the Holy One, their own interrelationship will be blessed with wholeness, with divine shalom.

\section{Appendix 1}

Fundamental Principles of a Catholic Theology of Shalom

\section{A Catholic Theology of Shalom}

\section{Sees Jews and Christians as Co-covenanting Companions}

A. Christianity and Judaism are intertwined theologically and historically.

B. Jews and Christians both covenant with God.

C. Jews and Christians are covenanting with the Holy One in distinctive yet resonating ways.

\section{Respects and Reckons with Jewish Self-Understanding}

A. All branches of theology require accuracy about Judaism past and present.

B. The Jewish and Christian traditions are in dialogue.

C. Mutuality in theologizing is preferable to binary or oppositional thinking.

\section{Focuses on Final Fulfillment in the Future}

A. Jews and Christians have different but converging expectations.

B. Jews and Christians have proleptically experienced God's ultimate future.

C. God's freedom of action, God's "mystery," is a primary reality.

${ }^{58}$ Jorge Mario Bergoglio, "The Façade as a Mirror," in Jorge Mario Bergoglio and Abraham Skorka, On Heaven and Earth: Pope Francis on Faith, Family, and the Church in the Twenty-First Century, trans. Alejandro Bermudez and Howard Goodman (New York: Image Books, 2013), xiv.

${ }^{59} \mathrm{I}$ am indebted to Celia Deutsch for using this phraseology in personal correspondence. 


\section{Appendix 2}

\section{"Synagoga and Ecclesia in Our Time," by Sculptor Joshua Koffman}

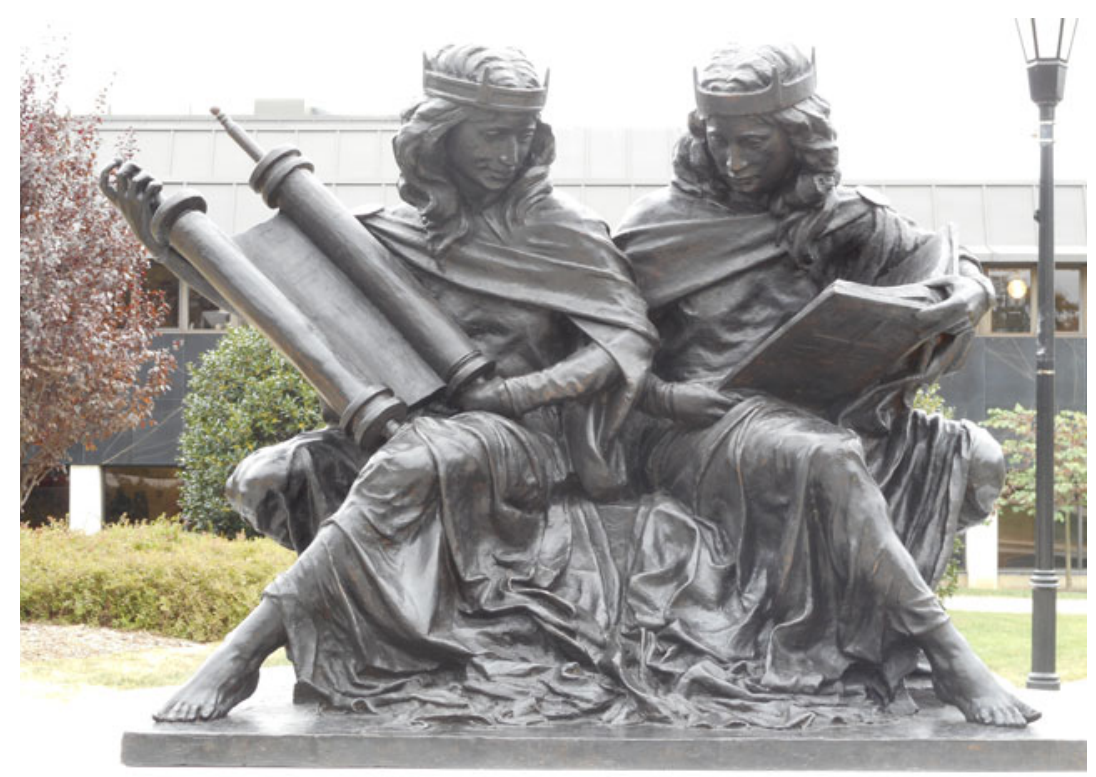

Photo credit: Philip A. Cunningham

Reimagining the medieval motif that portrayed a crowned and majestic Ecclesia (Church) triumphing over a blindfolded, crownless, and defeated Synagoga (Synagogue), this original sculpture portrays Jews and Christians as havruta, or study partners. Together they study their respective sacred texts and learn about their experiences of covenanting with God. The artwork was commissioned by Saint Joseph's University in Philadelphia to mark the golden jubilee of the Second Vatican Council declaration Nostra Aetate, and to commemorate the mission of the university's Institute for Jewish-Catholic Relations. After blessing the sculpture during a campus visit on September 27, 2015, Pope Francis was embraced by his longtime friend Rabbi Abraham Skorka, who, pointing to the female figures, said: "They are you and I, pope and rabbi learning from each other." This is a vision of mutuality between Christians and Jews in the future. 